\title{
Vitamin A deficiency in Crohn's disease
}

\author{
A N H MAIN, P R MILLS, R I RUSSELL, JOAN BRONTE-STEWART, \\ LESLEY M NELSON, A MCLELLAND, AND A SHENKIN \\ From the Gastroenterology Unit and Department of Biochemistry, Royal Infirmary and Tennent Institute of \\ Ophthalmology, Western Infirmary, Glasgow, Scotland
}

SUMmaRY Fifty two patients with Crohn's disease (31 outpatients and 21 inpatients) were investigated for evidence of vitamin A deficiency. Eleven $(21 \%)$ had low plasma retinol concentrations $(<1.2 \mu \mathrm{mol} / 1(34.3 \mu \mathrm{g} \%))$. Five of these were outpatients and plasma retinol was only slightly reduced $(>1.0 \mu \mathrm{mol} / \mathrm{l}(28.6 \%))$. All outpatients weighed $80 \%$ or more of ideal, and were considered at low risk of developing vitamin A deficiency. In contrast, of the six inpatients with low plasma retinol concentration, five had a level of $<1.0 \mu \mathrm{mol} / 1(28.6 \mu \mathrm{g} \%)$ and weighed $<80 \%$ ideal. Three of these had impaired dark adaptation and a plasma retinol concentration of $<0.8 \mu \mathrm{mol} / 1(<22.9 \mu \mathrm{g} \%)$. As a group, the inpatients were more protein depleted than the outpatients, with respect to serum albumin $(\mathrm{p}<0.01)$, transferrin $(\mathrm{p}<0.001)$, and prealbumin $(\mathrm{p}<0.001)$ but retinol binding protein levels were not significantly lower. It is suggested that patients with extensive small bowel Crohn's disease, who weigh $<80 \%$ of ideal weight, merit measurement of plasma retinol concentration. Those with plasma retinol $<0.8 \mu \mathrm{mol} / 1(<22.9$ $\mu \mathrm{g} \%$ ) run a high risk of night blindness. Vitamin supplements should be given and protein depletion corrected.

Among various reports of vitamin A deficiency in gastrointestinal and liver diseases, ${ }^{1-4}$ relatively few patients with Crohn's disease have been studied. There has been inadequate documentation of the prevalence of vitamin A deficiency in patients with Crohn's disease who are a population at risk of protein malnutrition or fat malabsorption as a result of diseased or resected small bowel. The first aim of this study was therefore to survey a large group of patients with Crohn's disease to define the prevalence of vitamin A deficiency. Two of our patients in hospital with extensive small bowel disease complained of night blindness and were found to have a severe defect of dark adaptation. Our second aim was therefore to carry out a more detailed study of patients in hospital in which we have attempted to define clinical and biochemical parameters which indicate a need for vitamin A supplementation.

\section{Methods}

PATIENTS

Fifty two patients were studied, 31 outpatients seen

Address for correspondence: Dr A Main, Gastroenterology Unit, Royal Infirmary, Glasgow G4 OSF.

Received for publication 18 Feburary 1983 at routine review (group 1) and 21 inpatients, admitted with exacerbations or complications of their disease (group 2). None of the patients was receiving vitamin A supplements. Body weight was recorded, expressed as a percentage of ideal weight based on WHO tables. ${ }^{5}$ Extent of small bowel disease and of resective small bowel surgery were recorded. Extensive disease was arbitrarily defined as disease or resections of the small bowel not confined to the terminal $60 \mathrm{~cm}$ of ileum. Blood samples were obtained for measurement of plasma retinol and plasma proteins, including albumin, transferrin, retinol binding protein, and prealbumin.

Analytical methods for biochemical parameters were as follows: plasma albumin and transferrin by standard laboratory techniques with reference ranges obtained from normal populations and retinol binding protein and prealbumin by a radial immunodiffusion technique using a commercial kit (LC-Partigen, Behring Company, West Germany) based on the method of Mancini. ${ }^{6}$ This method detects prealbumin reliably down to levels of $30 \mathrm{mg} / 1$ and retinol binding protein down to $5 \mathrm{mg} / \mathrm{l}$. Plasma retinol was assayed by fluorimetry based on the method of $\mathrm{Kahan}^{7}$ with modifications by Thompson. ${ }^{8}$ Normal ranges were established from 100 hospital orthopaedic patients without systemic 
disease. Serum zinc was measured by flame atomic absorption spectrophotometry. ${ }^{9}$ Fat absorption was measured by means of a dual isotope fat absorption technique developed in our own laboratory. ${ }^{10}$ The method measures percentage absorption of an ingested ${ }^{14} \mathrm{C}$-labelled triglyceride. Mean daily faecal fat excretion ${ }^{11}$ was based on three to five day collections of faeces.

Dark adaptation testing was performed using a Tubinger Perimeter adapted for dark adaptation testing (Oculus Optikgeräte, Wetzlar, West Germany). After bleaching retinal visual pigment by exposing the retina to white light of luminous intensity 3000 apostilbs (approximately 9500 candelas $/ \mathrm{m}^{2}$ ) for 15 minutes, a small area $12-14^{\circ}$ on the nasal side of the left eye was the focus of light of increasing intensity until the light was first perceived (the visual threshold). This was retested every two minutes until no improvement could be achieved, usually after 20-30 minutes. This final visual threshold, generally accepted as a sensitive indicator of vitamin A deficiency was measured in nine of the 21 hospitalised patients (group 2), those with plasma retinol $<1.4 \mu \mathrm{mol} / 1(40 \mu \mathrm{g} \%)$. Fourteen normal subjects were tested to establish a normal range based upon the mean and two SDs (43.4-55.4 negative $\log _{10}$ apostilbs), higher numbers indicating lower luminous intensity. Conversion factor apostilbs $\times 3 \cdot 142=$ candela $/ \mathrm{m}^{2}$. All patients were also examined for other manifestations of xerophthalmia based on the most recent WHO classification. ${ }^{12}$

\section{STATISTICAL METHODS}

The relationship between retinol levels and the various plasma proteins was tested by linear regression analysis. Differences between populations were assessed by a Mann-Whitney test. Mean values and standard deviations are also quoted where appropriate.

\section{Results}

The 52 patients consisted of 17 men and 35 women of mean age 39 years. Their mean (range) body weight was $90 \%(54-149 \%)$ ideal. Outpatients (group 1) tended to weigh more (100\% (80-149\%)) than inpatients (group 2$)(76 \%(54-103 \%))$. Twenty patients had extensive small bowel disease, 10 in each group. Results of the biochemical analyses are shown in Table 1. Plasma proteins, apart from retinol binding protein, were lower in group 2 than in group 1. There was no association between plasma retinol levels and serum albumin or transferrin, but a significant correlation was shown between retinol and retinol binding protein (Fig. 1), between retinol and prealbumin $(r=0.71 ; p<0.001)$, and between retinol binding protein and prealbumin $(r=0.81 ; p<0.001)$.

Based on our normal range, 11 of the 52 patients $(21 \%)$ had low plasma retinol levels. Five were in group 1 (Table 2) and these outpatients were not further studied. The remaining six patients with plasma retinol $<1.2 \mu \mathrm{mol} / \mathrm{l}(34 \mu \mathrm{g} \%)$ were in group 2 . These and a further three patients with plasma retinol $>1.2$ but $<1.4 \mu \mathrm{mol} / 1$ were selected for further studies. These nine were compared with the remaining 12 patients in group 2 (Table 3 ). The results of further studies on these nine 'high risk' patients are shown in Table 4. Five (nos 1, 2, 4, 5, 6) had impaired fat absorption and a marked increase in faecal fat excretion. Three (nos 3, 4, 6) had impaired dark adaptation testing as indicated by a raised final visual threshold $\left(<43.4\right.$ neg $\log _{10}$ apostilbs) but only patients 4 and 6 complained of night blindness. None of the patients had conjunctival or retinal signs of xerophthalmia.

Patient 3 had only $140 \mathrm{~cm}$ of small bowel remaining after previous resections for obstructive Crohn's disease. After an exacerbation with severe diarrhoea and weight loss he was noted to have a

Table 1 Plasma proteins and retinol levels in outpatients (group 1) and inpatients (group 2)

\begin{tabular}{|c|c|c|c|c|c|}
\hline & $\begin{array}{l}\text { Albumin } \\
(\mathrm{g} / \mathrm{l})\end{array}$ & $\begin{array}{l}\text { Transferrin } \\
(\mathrm{g} / \mathrm{l})\end{array}$ & $\begin{array}{l}\text { Retinol binding } \\
\text { protein } \\
(\mathrm{mg} / \mathrm{l})\end{array}$ & $\begin{array}{l}\text { Prealbumin } \\
(\mathrm{mg} / \mathrm{l})\end{array}$ & $\begin{array}{l}\text { Retinol } \\
(\mu \mathrm{mol} / \mathrm{l}(\mu \mathrm{g} \%))\end{array}$ \\
\hline Normal ranges & $35-50$ & $2 \cdot 0-4 \cdot 0$ & $\begin{array}{l}\text { M } 32-91 \\
\text { F } 28-76\end{array}$ & $\begin{array}{ll}\text { M } & 215-400 \\
\text { F } & 165-365\end{array}$ & $\begin{array}{l}1 \cdot 2-2 \cdot 9 \\
(34-83)\end{array}$ \\
\hline All patients (52) & $37 \cdot 2 \pm 6 \cdot 2^{*}$ & $2 \cdot 8 \pm 0 \cdot 8$ & $42 \cdot 0 \pm 15 \cdot 1$ & $235 \pm 87$ & $\begin{array}{l}1 \cdot 7 \pm 0 \cdot 9 \\
(48 \cdot 6 \pm 25 \cdot 7)\end{array}$ \\
\hline Group 1 (31) & $39 \cdot 8 \pm 4 \cdot 4$ & $3 \cdot 2 \pm 0 \cdot 6$ & $44 \cdot 6 \pm 12 \cdot 3$ & $270 \pm 77$ & $\begin{array}{l}1 \cdot 8 \pm 1 \cdot 0 \\
(51 \cdot 5 \pm 28 \cdot 6)\end{array}$ \\
\hline Group 2 (21) & $33 \cdot 7 \pm 6 \cdot 6$ & $2 \cdot 2 \pm 0 \cdot 7$ & $37 \cdot 2 \pm 18 \cdot 7$ & $172 \pm 66$ & $\begin{array}{l}1 \cdot 5 \pm 0 \cdot 8 \\
(42 \cdot 9 \pm 22 \cdot 9)\end{array}$ \\
\hline $\mathrm{p}$ value ${ }^{\dagger}$ & $<0.01$ & $<0.001$ & NS & $<0.001$ & NS \\
\hline
\end{tabular}

* Mean \pm SD. † Comparisons between group 1 and group 2. NS = not significant. 
Table 2 Clinical and biochemical characteristics of group 1 patients with low plasma retinol concentrations $(<1 \cdot 2 \mu m o l l l)$

\begin{tabular}{|c|c|c|c|c|c|c|c|}
\hline Patient & $\operatorname{Sex}$ & Age & $\begin{array}{l}\text { Extent of } \\
\text { small bowel } \\
\text { disease }\end{array}$ & $\begin{array}{l}\text { Body weight } \\
\text { (\% ideal) }\end{array}$ & $\begin{array}{l}\text { Retinol } \\
(\mu \mathrm{mol} / \mathrm{l}(\mu \mathrm{g} \%))\end{array}$ & $\begin{array}{l}\text { Retinol binding } \\
\text { protein } \\
(m g / l)\end{array}$ & $\begin{array}{l}\text { Prealbumin } \\
(\mathrm{mg} / \mathrm{l})\end{array}$ \\
\hline 1 & $\mathrm{~F}$ & 31 & L & 90 & $1 \cdot 1(31 \cdot 5)$ & 22 & 145 \\
\hline 2 & $\mathbf{F}$ & 54 & $E$ & 90 & $1.0(28.6)$ & 32 & 235 \\
\hline 3 & $\mathbf{F}$ & 29 & $\mathrm{E}$ & 85 & $1 \cdot 0(28 \cdot 6)$ & 35 & 185 \\
\hline 4 & $\mathbf{F}$ & 27 & L & 85 & $1.0(28.6)$ & 35 & 255 \\
\hline 5 & M & 30 & $E$ & 97 & $1 \cdot 1(31 \cdot 5)$ & 29 & 155 \\
\hline \multicolumn{4}{|c|}{$E=$ extensive $\mathrm{L}=$ localised } & Normal ranges & $\begin{array}{l}1 \cdot 2-2 \cdot 9 \\
(34-83)\end{array}$ & $\begin{array}{l}\text { M } 32-91 \\
\text { F } 28-76\end{array}$ & $\begin{array}{ll}\text { M } & 215-400 \\
\text { F } & 165-365\end{array}$ \\
\hline
\end{tabular}

plasma retinol concentration of only $0 \cdot 2 \mu \mathrm{mol} / 1(5 \cdot 7$ $\mu \mathrm{g} \%)$, associated with low retinol binding protein $(24 \mathrm{mg} / \mathrm{l})$ and low prealbumin $(95 \mathrm{mg} / \mathrm{l})$. Despite abnormal dark adaptation testing he complained of no visual impairment.

Patient 4 , a man with diffuse small bowel disease and steatorrhoea, had required four periods of intravenous nutrition (IVN) before 1981 because of recurrent weight loss and hypoproteinaemia. During the seven months before he noticed night blindness

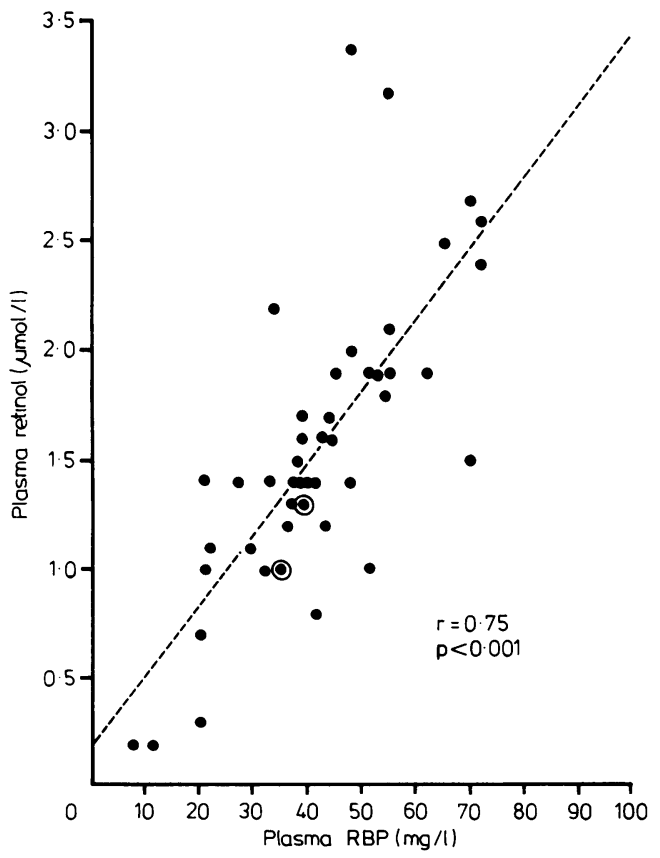

Fig. 1 Correlation between plasma concentrations of retinol and retinol binding protein. $O$ indicates two or more identical values.
(Fig. 2) there was a fall in serum albumin and transferrin and very low levels of retinol, retinol binding protein, and prealbumin were noted. Dark adaptation testing at that time was impaired (Fig. 3upper curve). As shown in Fig. 2 there was a rapid improvement in proteins and plasma retinol over a 14 day period on intravenous nutrition including vitamin A supplements, concurrent with resolution of his visual symptoms and return of his dark adaptation testing to normal (Fig. 3 - lower curve).

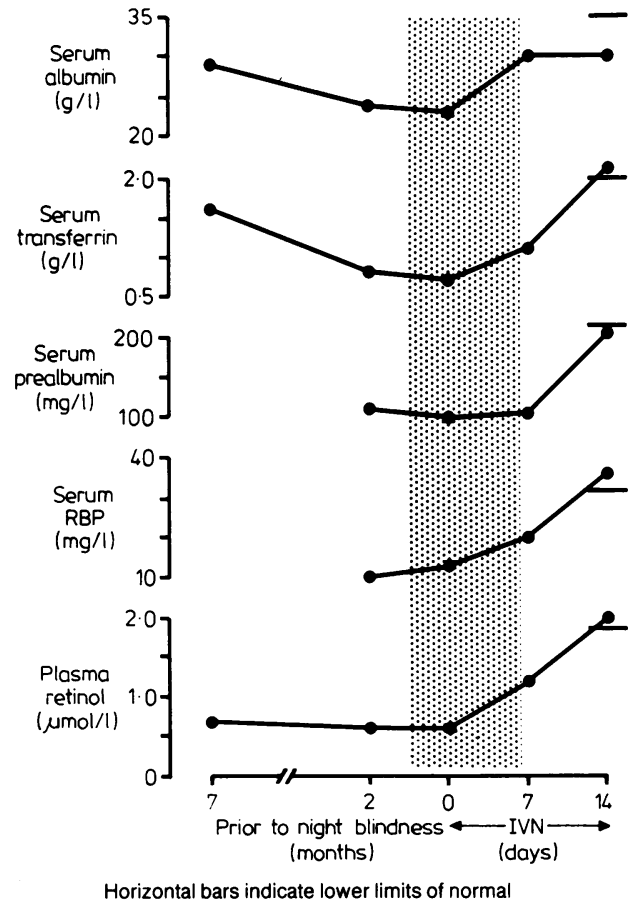

Fig. 2 Biochemical changes before and after treatment with IVN including vitamin A (2500 IU/d) in patient 4 (Table 4). Cross hatched area indicates time during which he complained of night blindness. 
Table 3 Clinical and biochemical comparison between high risk and low risk patients in group 2

\begin{tabular}{|c|c|c|c|c|}
\hline & $\begin{array}{l}\text { Plasma retinol } \\
<1.4 \mu \mathrm{molll}(9) \\
(<40 \mu \mathrm{g} \%)\end{array}$ & & $\begin{array}{l}\text { Plasma retinol } \\
\geqslant 1.4 \mu \mathrm{mol} / \mathrm{l}(12) \\
(\geqslant 40 \mathrm{\mu g} \%)\end{array}$ & \\
\hline $\begin{array}{l}\text { Presence of extensive disease } \\
\text { Mean body weight (\% ideal) }\end{array}$ & $\begin{array}{l}7 \text { out of } 9 \\
71 \%\end{array}$ & NS & $\begin{array}{l}3 \text { out of } 12 \\
82 \%\end{array}$ & \\
\hline Serum values (mean $\pm S D$ ) & & & & Normal range \\
\hline Albumin $(\mathrm{g} / \mathrm{l})$ & $31 \cdot 1 \pm 6 \cdot 2$ & NS & $34 \cdot 3 \pm 7 \cdot 7$ & $35-51$ \\
\hline Transferrin $(\mathrm{g} / \mathrm{l})$ & $1 \cdot 7 \pm 0 \cdot 8$ & $\mathrm{p}<0.05$ & $2 \cdot 4 \pm 0 \cdot 7$ & $2 \cdot 0-4 \cdot 0$ \\
\hline Retinol binding protein $(\mathrm{mg} / \mathrm{l})$ & $26 \cdot 5 \pm 15 \cdot 5$ & $\mathrm{p}<0.05$ & $49 \cdot 2 \pm 18 \cdot 1$ & $32-91$ \\
\hline Prealbumin $(\mathrm{mg} / \mathrm{l})$ & $135 \pm 66$ & $\mathrm{p}<0.05$ & $213 \pm 49$ & $215-400$ \\
\hline $\operatorname{Zinc}(\mu \mathrm{mol} / /(\mu \mathrm{g} \%))$ & $\begin{array}{r}9 \cdot 0 \pm 1 \cdot 5 \\
(59 \pm 10)\end{array}$ & NS & $12 \cdot 6 \pm 6 \cdot 2$ & $10 \cdot 0-18 \cdot 0$ \\
\hline
\end{tabular}

NS = not significant

Patient 6 (Fig. 4), a girl with chronic diarrhoea and steatorrhoea of 11 years duration, complained of severe night blindness and dark adaptation testing (upper line) was grossly abnormal. Plasma retinol was very low $(0.2 \mu \mathrm{mol} / \mathrm{l})$ as were retinol binding protein $(14 \mathrm{mg} / \mathrm{l})$ and prealbumin $(115 \mathrm{mg} / \mathrm{l})$. After oral vitamin A therapy (6000 IU/day) her symptoms rapidly improved with improvement of dark adaptation testing (lower line).

\section{Discussion}

This study has shown that vitamin A deficiency is a significant clinical problem in severe Crohn's disease. Impaired dark adaptation, the earliest sign of vitamin A deficiency, was present in three inpatients with Crohn's disease and was associated with extensive small bowel disease, very low plasma retinol concentrations, and depletion of plasma proteins, especially retinol binding protein and prealbumin. Two patients had in addition impaired fat absorption and severe steatorrhoea.
Among the various methods of assessing vitamin A status recently reviewed by Pitt, ${ }^{13}$ concentration of vitamin $A$ in liver tissue is the most sensitive guide to body status, as vitamin $\mathrm{A}$ is stored almost entirely in the liver. There may be, however, an uneven distribution of vitamin $\mathrm{A}$ in liver. ${ }^{14}$ Plasma retinol levels only fall when liver reserves are exhausted and therefore are relatively insensitive guides to vitamin A stores. ${ }^{13}$ Retinol concentration in plasma, however, is a reasonable screening test as clinical signs of vitamin A deficiency (impaired dark adaptation) do not appear to occur when plasma retinol levels are greater than $1.4 \mu \mathrm{mol} / \mathrm{l}(40 \mu \mathrm{g} \%){ }^{4}$ Despite differences between our method of measuring plasma retinol and that of Carney and Russell, ${ }^{4}$ we felt it was reasonable to define our 'high risk' patients (Table 3 ) as those with plasma retinol $<1.4 \mu \mathrm{mol} / \mathrm{l}$, and to undertake dark adaptation testing only on these patients. Furthermore, very low plasma retinol levels are useful in the clinical situation, as Carney and Russell, ${ }^{4}$ in a study of patients with a variety of diseases, reported that

Table 4 Further studies of group 2. Patients with plasma retinol $<1.4 \mu \mathrm{mol} / \mathrm{l}$

\begin{tabular}{|c|c|c|c|c|c|c|c|c|c|}
\hline Patient & Sex & Age & $\begin{array}{l}\text { Extent of } \\
\text { small } \\
\text { bowel } \\
\text { disease }\end{array}$ & $\begin{array}{l}\text { Body wt } \\
\text { (\% ideal) }\end{array}$ & $\begin{array}{l}\text { Final visual } \\
\text { threshold } \\
\text { (neg } \log _{10} \\
\text { apostilbs) }\end{array}$ & $\begin{array}{l}\text { Plasma } \\
\text { retinol } \\
(\mu \mathrm{mol} / \mathrm{l}) \\
(\mu \mathrm{g} \%)\end{array}$ & $\begin{array}{l}\text { Serum zinc } \\
(\mu \mathrm{mol} / \mathrm{l}) \\
(\mu g \%)\end{array}$ & $\begin{array}{l}\text { Tri- } \\
\text { glyceride } \\
\text { absorption } \\
(\%)\end{array}$ & $\begin{array}{l}\text { Faecal } \\
\text { fat } \\
(\mathrm{mmol} / \mathrm{d})\end{array}$ \\
\hline 1 & $\mathbf{F}$ & 60 & $\mathrm{E}$ & 83 & 44 & $1 \cdot 2(34 \cdot 3)$ & $7 \cdot 2(47)$ & 15 & 179 \\
\hline 2 & $\mathbf{M}$ & 48 & $\mathrm{E}$ & 80 & 44 & $1 \cdot 0(28 \cdot 6)$ & $11 \cdot 0(72)$ & 44 & 168 \\
\hline 3 & $\mathbf{M}$ & 16 & $\mathrm{E}$ & 74 & 38 & $0 \cdot 2(5 \cdot 7)$ & $10 \cdot 5(68)$ & 98 & 27 \\
\hline 5 & $\mathbf{F}$ & 19 & $\mathrm{E}$ & 64 & 46 & $0 \cdot 6(17 \cdot 2)$ & $6 \cdot 5(42)$ & 82 & 49 \\
\hline 6 & $\mathbf{F}$ & 18 & $\mathrm{E}$ & 54 & 25 & $0 \cdot 2(5 \cdot 7)$ & $4 \cdot 5(29)$ & 16 & 153 \\
\hline 7 & $\mathbf{F}$ & 16 & L & 69 & 57 & $1 \cdot 3(37 \cdot 2)$ & $10 \cdot 0(65)$ & 96 & 16 \\
\hline 8 & $\mathbf{F}$ & 71 & $\mathrm{~L}$ & 70 & 45 & $1 \cdot 3(37 \cdot 2)$ & $8 \cdot 5(55)$ & - & 22 \\
\hline 9 & $\mathbf{F}$ & 26 & $\mathrm{E}$ & 70 & 46 & $0.8(22.9)$ & $10 \cdot 0(65)$ & - & - \\
\hline & & & & al ranges & $>43.4$ & $\begin{array}{l}1 \cdot 2-2 \cdot 9 \\
(34-83)\end{array}$ & $\begin{array}{l}10 \cdot 0-18 \cdot 0 \\
(65-117)\end{array}$ & $\geqslant 96 \%$ & $<21$ \\
\hline
\end{tabular}




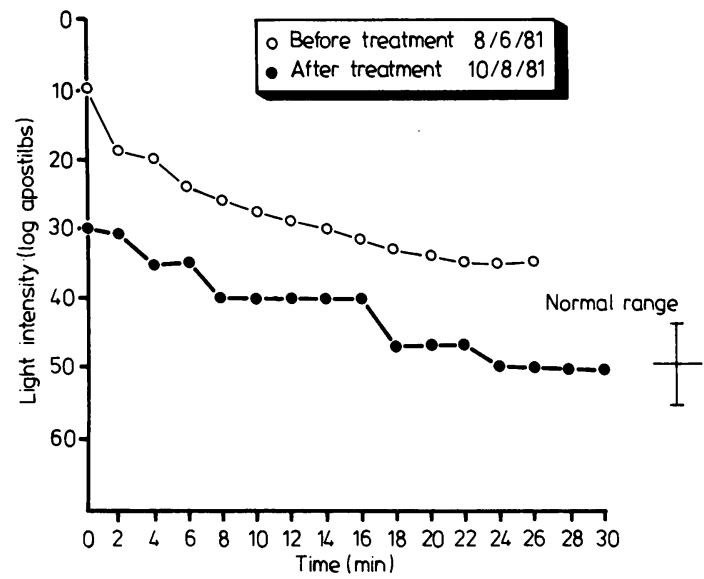

Fig. 3 Dark adaptation testing before (upper curve) and after IVN followed by oral vitamin A therapy in patient 4.

15 out of 21 patients with plasma retinol $<1.05$ $\mu \mathrm{mol} / \mathrm{l}(<30 \mu \mathrm{g} \%)$ had abnormal dark adaptation testing. In this study three out of four patients with plasma retinol $<0.8 \mu \mathrm{mol} / \mathrm{l} \quad(<23 \mu \mathrm{g} \%)$ had abnormal dark adaptation testing, whereas in no patient with plasma retinol $>0.8 \mu \mathrm{mol} / \mathrm{l}$ was dark adaptation testing abnormal.

In developed countries, vitamin A deficiency is unlikely to occur for dietary reasons alone and the search for clinical evidence of vitamin A deficiency has therefore centred on patients with liver disease $^{2-4}$ and various gastrointestinal diseases ${ }^{134}$ among which some patients with Crohn's disease have been included.

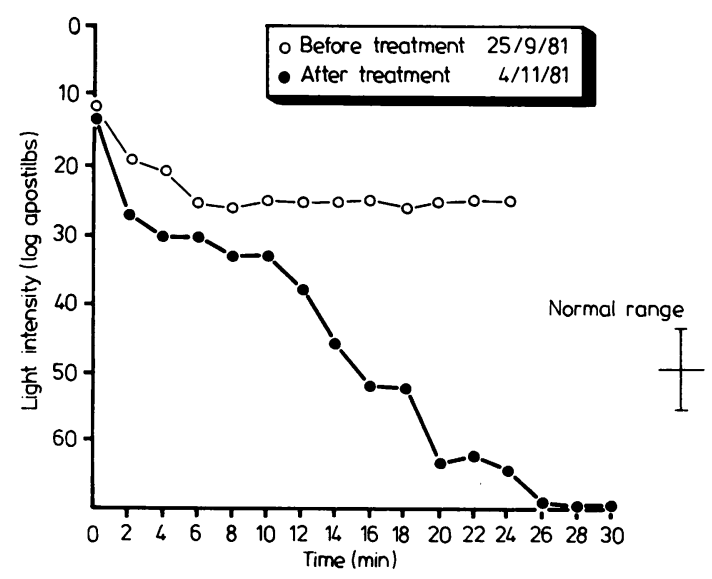

Fig. 4 Dark adaptation testing before (upper curve) and after oral vitamin $A$ therapy in patient 6.
Patients with severe Crohn's disease may be protein depleted as we have shown. Indeed, retinol binding protein and prealbumin which have a relatively short half-life are more senitive to protein or energy deprivation than albumin or transferrin. ${ }^{15}$ Plasma concentrations of retinol binding protein and prealbumin fall rapidly in protein malnutrition and rise on refeeding. ${ }^{16}$ The expected close relationship between retinol, retinol binding protein, and prealbumin in plasma ${ }^{17}{ }^{18}$ has been confirmed in our patients with Crohn's disease and emphasises the importance of adequate protein nutrition for transport of retinol to its target tissues, principally the retina. If protein malnutrition is not corrected, plasma retinol and retinol binding protein levels may remain low despite adequate intake of vitamin A. ${ }^{19}$ Fat malabsorption was a significant problem in some patients, and might be expected to result in vitamin A deprivation which has been shown to inhibit release of hepatic retinol binding protein into the circulation. ${ }^{20}$ Repletion of vitamin A results in a fall in hepatic retinol binding protein and a rise in serum retinol binding protein. ${ }^{21}$ Assessment of the relative importance of protein depletion and fat malabsorption in the pathogenesis of xerophthalmia in our patients was difficult because only three had impaired dark adaptation. All three, however, were protein depleted and two had fat malabsorption. Vahlquist and his colleagues, ${ }^{3}$ studying patients with various gastrointestinal diseases, showed an association between steatorrhoea and low plasma retinol binding protein levels, and between very low retinol binding protein levels and impaired dark adaptation. No direct relationship between steatorrhoea and impaired dark adaptation, however, was suggested.

The possibility that zinc deficiency might contribute to the pathogenesis of vitamin A deficiency has received some attention in the literature in animals ${ }^{22}{ }^{23}$ and in humans. ${ }^{24}$ The effect is probably because of the depression of protein synthesis and in particular impaired synthesis of prealbumin ${ }^{24}$ and retinol binding protein. ${ }^{23}$ Serum zinc levels were not significantly different in the two groups (Table 3). We recognise, however, as discussed in a previous report, ${ }^{25}$ that serum zinc levels alone are not good indicators of zinc nutriture.

It was not possible to predict from the extent of small bowel disease alone which patients were at risk from vitamin A deficiency. The presence of only localised disease did not exclude low plasma retinol levels. Conversely, extensive disease was compatible with normal plasma retinol levels. None of the five patients with very low levels of retinol $(<1.0 \mu \mathrm{mol} / 1)$, however, had localised disease and it 
may be that patients with localised disease are unlikely to develop vitamin A deficiency.

Body weight measurement may be more useful. The outpatient group seemed at lower risk than the inpatients. All had plasma retinol levels $>1.0 \mu \mathrm{mol} / 1$ $(28.6 \mu \mathrm{g} \%)$ and weighed $>80 \%$ of ideal body weight. In contrast the five who had plasma retinol levels $<1.0 \mu \mathrm{mol} / 1$ were all inpatients admitted with exacerbations or complications. All five, including the three with impaired dark adaptation, weighed $<80 \%$ of ideal weight (Table 4 - patients $3,4,5$, $6,9)$.

It could be argued that night blindness is readily reversible and tests could therefore be reserved for those patients who admit to the symptom on direct questioning. One of the three patients with impaired dark adaptation testing, however, was asymptomatic and direct questioning may not be completely reliable in the detection of retinal impairment. Furthermore, protein depletion, which has adverse effects unrelated to vitamin A deficiency, may be far advanced before night blindness develops. It seems reasonable, therefore, to improve protein status before night blindness occurs.

\section{Conclusions and recommendations}

We would suggest that patients with extensive small bowel Crohn's disease who weigh $<80 \%$ of ideal weight should have biochemical tests performed including measurement of plasma retinol and plasma proteins. Our data suggest that patients with plasma retinol $<0.8 \mu \mathrm{mol} / \mathrm{l}(23 \mu \mathrm{g} \%)$ run a high risk of developing night blindness which may be subclinical. If dark adaptation testing is not possible we would suggest that vitamin A supplements should be given. Protein depletion which is likely to be present should also be corrected.

The Gastroenterology Unit wish to thank Travenol Laboratories for their support.

\section{References}

1 Russell RM, Smith VC, Multack R, Krill AE, Rosenberg IH. Dark adaptation testing for diagnosis of subclinical vitamin $A$ deficiency and evaluation of therapy. Lancet 1973; 2: 1161-4.

2 Russell RM, Morrison SA, Smith FR, Oaks EV, Carney EA. Vitamin A reversal of abnormal dark adaptation in cirrhosis - study of effects on the plasma retinol transport system. Ann Intern Med 1978; 88:
622-6.

3 Vahlquist A, Sjölund K, Norden $\AA$, Peterson PA, Stigmar G, Johansson B. Plasma vitamin A transport and visual dark adaptation testing in diseases of the intestine and liver. Scand J Clin Lab Invest 1978; 38: 301-8.

4 Carney EA, Russell RM. Correlation of dark adaptation test results with serum vitamin A levels in diseased adults. J Nutr 1980; 110: 552-7.

5 Jelliffe DB. The assessment of the nutritional status of the community. Monograph No 53. Geneva: WHO, 1966.

6 Mancini G, Carbonara AO, Heremans JF. Immunochemical quantitation of antigens by single radial immunodiffusion. Immunochemistry 1965; 2: 235-54.

7 Kahan J. A method for the fluorimetric determination of vitamin A. Scand J Clin Lab Invest 1966; 18: 679-90.

8 Thompson JN, Erdody P, Maxwell WB. Simultaneous fluorimetric determinations of vitamin $\mathrm{A}$ and $\mathrm{E}$ in human serum and plasma. Biochem Med 1973; 8: 403-14.

9 Peaston ET. The determination of zinc and copper in plasma and urine. Med Lab Technol 1973; 30: 249-53.

10 Nelson LM, MacKenzie JF, Russell RI. Measurement of fat absorption using $\left[{ }^{3} \mathrm{H}\right]$ glycerol triether and $\left[{ }^{14} \mathrm{C}\right]$ glycerol trioleate in man. Clin Chim Acta 1980; 103: 325-34.

11 Van de Kamer JH, Bokkel-Huinink HT, Weyers HA. Rapid method for the determination of fat in faeces. J Biol Chem 1949; 177: 347-55.

12 Anonymous. Vitamin A deficiency and xerophthalmia. Tech Rep WHO Ser No 672. Geneva: WHO, 1982.

13 Pitt GAJ. The assessment of vitamin A status. Proc Nutr Soc 1981; 40: 173-8.

14 McLaren DS, Mawlayi Z, Downing A. Distribution of vitamin A in human liver. Proc Nutr Soc 1979; 38: 49A.

15 Shetty PS, Watrasiewicz KE, Jung RT, James WPT. Rapid turnover transport proteins: an index of subclinical protein-energy malnutrition. Lancet 1979; 2: 230-2.

16 Coward WA, Lunn PG. The biochemistry and physiology of Kwashiorkor and Marasmus. Br Med Bull 1981; 37: 19-24.

17 Goodman DS. Vitamin A transport and retinol-binding protein metabolism. Vitam Horm (NY) 1974; 32: 167-80.

18 Goodman DS. Retinol-binding protein, prealbumin and vitamin A transport. In: Jamieson GS, Greenwalt $\mathrm{TJ}$, eds. Trace components of plasma: isolation and clinical significance. New York: Liss, 1976: 313-30.

19 Smith FR, Goodman DS, Zaklama MS, Gabr MK, ElMaraghy S, Patwardhan VN. Serum vitamin A retinol-binding protein and prealbumin concentrations in protein-calorie malnutrition. 1. A functional defect in hepatic retinol release. Am J Clin Nutr 1973; 26: 973-81.

20 Mato Y, Smith JE, Goodman DS. Regulation of retinol-binding protein metabolism by vitamin A status in the rat. $J$ Biol Chem 1972; 247: 2542-50.

21 Smith JE, Goodman DS. Retinol-binding protein and the regulation of vitamin A transport. Fed Proc 1979; 38: 2504-9. 
22 Smith JC Jr, McDaniel EG, Fan FF, Halsted JA. Zinc: a trace element essential in vitamin A metabolism. Science 1973; 181: 954-5.

23 Smith JE, Brown ED, Smith JC Jr. The effect of zinc deficiency on the metabolism of retinol-binding protein in the rat. J Lab Clin Med 1974; 84: 692-7.

24 Bates J, McClain CJ. The effect of severe zinc deficiency on serum levels of albumin, transferrin, and prealbumin in man. Am J Clin Nutr 1981; 34: 1655-60.

25 Main ANH, Hall MJ, Russell RI, Fell GS, Mills PR, Shenkin A. Clinical experience of zinc supplementation during intravenous nutrition in Crohn's disease: value of serum and urine zinc measurements. Gut 1982; 23: 984-91. 